\title{
The influence of the Chinese ideogram on Ezra Pound's cathay
}

\author{
A. Serdar Öztürk ${ }^{*}$
}

\begin{abstract}
Ezra pound is among the most important poets of world literature in the twentieth century. His influence on English poetry, especially on T. S. Eliot was very great. His name is associated with the school of poetry called Imagism. Cathay is a volume of his translations from the Chinese which reveals the Chinese poetry. Chinese verse lends itself especially to the imagist treatment because of the visual nature of the Chinese ideogram. Ezra Pound was successful in translating the Chinese image in Cathay.
\end{abstract}

Keywords: Ezra Pound, Imagist, Cathay, Ideogram

Corresponding author: A. Serdar Öztürk, Faculty of Arts and Social Scinces, International Sarajevo University, Bosnia Herzegovina, e-mail: aozturk@ius.edu.ba 
Ezra Pound's name is closely associated with the school of poetry called Imagism. Students of Pound are well acquainted with his early admiration and earnest support of Les Imagistes; namely, H.D., T. E. Hulme, and John Gould Fletcher. It was, in fact, Pound himself who is largely responsible for coining the term Imagiste; as he writes in 'A Retrospect': "[T] he first use of the word 'Imagiste' was in my note to T. E. Hulme's five poems, printed at the end of my 'Rispostes' in the autumn of 1912." (Literary Essays 4). Between the publication of the Rispostes volume and the appearance of his monumental The Cantos, Pound had been busy experimenting in some of his shorter verse with Imagiste technique. This is especially true in Lustra in such poems as 'April', 'Gentildonna', 'Liu Ch'e', 'Fan piece, for her Imperial Lord', 'Alba', and 'In a Station of the Metro'. The one early collection, however, which most greatly abounds with Imagiste touches is Cathay, a volume of Pound's translations from the Chinese. An exploration of the influence of Les Imagistes on these translations will reveal that Chinese poetry, by its very nature, not only appealed to the Imagiste poet, but practically resisted any but Imagistic treatment.

Following her conversion to the Imagist movement in 1913, Amy Lowell gives a fairly inclusive discussion of the aims of the Imagiste school in her study Tendencies in Modern American Poetry:

1. To use the language of common speech, but to employ always the exact word-not the nearly exact;

2. To strive always for concentration which, the imagist was convinced, is the very essence of poetry;

3. To suggest rather than to offer complete statement;

4. To create new rhythms as the expressions of new moods - and not to copy old rhythms which merely echo old moods;

5. To present an image; i.e., one that is concrete, firm, sharply delineated, and harsh in outline (236).

Less than a year before Lowell had announced her allegiance to H.D. and the Imagist cause, Pound, H.D., and Richard Aldington had agreed on three principles defining 'a new fashion' in poetry:

1. Direct treatment of the 'thing' whether subjective or objective.

2. To use absolutely no word that does not contribute to the presentation.

3. As regarding rhythm: to compose in the sequence of the musical phrase, not in the sequence of a metronome (Literary Essays 4). 
These statements of a poetic credo, without the body of poetry they attempt to define, are open to multiple interpretations. It is surely an irony that a poetic school demanding visual acuity, concise expression, and le mot juste should, in many respects, escape clear, precise definition. Even though Imagism sets forth certain principles of composition, the significance of Imagism lies more in its transcendence of these principles than in its mere adherence to them. That is to say Imagism is more in the nature of an aesthetics, which promotes a certain attitude toward writing, rather than inflexible doctrine. Nevertheless, by an examination of the precepts of Imagism, as they are given form in the poems of Cathay, it is possible to approach an understanding of the spirit of Les Imagistes.

Chinese verse, it will be argued, lends itself especially well to imagistic treatment. This is due partly to the sharply defined, visual nature of the Chinese ideogram, as Pound discovered in Fenollosa's manuscript 'Chinese Written Character as a Medium for Poetry'. Many of the striking images in the Cathay poems, in fact, derive their efficacy directly from the force of Chinese ideogrammic expression. As, for example, when Pound employs the picture of 'dragon-like horses' in 'Poem by the Bridge at Ten-Shin':

This jungle poem is going to be my last.

This space walk is.

Racing in a cab through springtime Central Park,

I kept my nose outside the window like a dog.

The stars above my bed at night are vast.

I think it is uncool to call young women Ms.

My darling is a platform I see stars from in the dark,

And all the dogs begin to bark.

My grunting gun brings down her charging warthog,

And she is frying on white water, clinging to a log,

And all the foam and fevers shiver.

And drink has made chopped liver of my liver!

Between my legs it's Baudelaire.

He wrote about her Central Park of hair.

I look for the minuterie as if I were in France,

In darkness, in the downstairs entrance, looking for the light.

I'm on a timer that will give me time

To see the way and up the stairs before the lights go out.

The so delicious Busby Berkeley dancers dance

A movie musical extravaganza on the staircase with me every night.

Such fun! We dance. We climb. We slip in slime.

We're squirting squeezes like a wedge of lime! 
It's like a shout.

It's what minuterie is all about.

Just getting to the landing through the dark

That has been interrupted for a minute is a lark.

And she's so happy. It is grand!

I put my mobile in her ampersand.

The fireworks are a fleeting puff of sadness.

The flowers when they reach the stars are tears.

I don't remember poems I write.

I turn around and they are gone.

I do remember poor King Richard Nixon's madness.

Pierre Leval, we loved those years!

We knocked back shots of single malt all night.

Beer chasers gave dos caballeros double vision, second sight-

Twin putti pissing out the hotel window on the Scottish dawn.

A crocodile has fallen for a fawn.

I live flap copy for a children's book.

He wants to lick. He wants to look.

A tiny goldfinch is his Cupid.

Love of cuntry makes men stupid.

It makes men miss Saddam Hussein!

Democracy in Baghdad makes men think

Monstrosity was not so bad.

I followed Gandhi barefoot to

Remind me there is something else till it began to rain.

The hurricane undressing of democracy in Baghdad starts to sink The shrunken page size of the New York Times, and yet we had A newspaper that mattered once, and that is sad,

But that was when it mattered. Do

I matter? That is true.

I don't matter but I do. I lust for fame,

And after never finding it I never was the same.

I roared into the heavens and I soared,

And landed where I started on a flexing diving board.

I knew a beauty named Dawn Green.

I used to wake at the crack of Dawn.

I wish I were about to land on Plymouth Rock,

And had a chance to do it all again but do it right.

It was green dawn in pre-America. I mean

Great scented forests all along the shore, which now are gone.

I've had advantages in life and I pronounce Iraq "Irrock."

The right schools taught me how to tock.

I'm tocking Turkey to the Kurds but with no end in sight.

These peace tocks are my last. Goodbye, Iran. Iran, good night.

They burned the undergrowth so they could see the game they hunt.

That made the forest a cathedral clear as crystal like a cunt.

Their arrows entered red meat in the glory

Streaming down from the clerestory.

Carine Rueff, I was obsessed-I was possessed! I liked your name. 
I liked the fact Marie Christine Carine Rue F was Jewish. It emphasized your elegance in Paris and in Florence.

You were so blond in Rue de l'Université!

The dazzling daughter of de Gaulle's adviser Jacques Rueff was game For anything. I'm lolling here in Mayfair under bluish

Clouds above a bench in Mount Street Gardens, thinking torrents.

Purdey used to make a gun for shooting elephants.

One cannot be the way one was back then today.

It went away.

I go from Claridge's to Brands Hatch racing circuit and come back

To Claridge's, and out and eat and drink and bed, and fade to black.

The elephants were old enough to die but were aghast.

The stars above this jungle poem are vast.

To Ninety-second Street and Broadway I have come.

Outside the windows is New York.

I came here from St. Louis in a covered wagon overland

Behind the matchless prancing pair of Eliot and Ezra Pound.

And countless moist oases took me in along the way, and some I still remember when I lift my knife and fork.

The Earth keeps turning, night and day, spit-roasting all the tanned

Tired icebergs and the polar bears, which makes white almost contraband.

The biosphere on a rotisserie emits a certain sound

That tells the stars that Earth was moaning pleasure while it drowned.

The amorous white icebergs flash their brown teeth, hissing.

They're watching old porn videos of melting icebergs pissing.

The icebergs still in panty hose are lesbians and kissing.

The rotting ocean swallows the bombed airliner that's missing.

He translates very closely the following pair of ideograms:
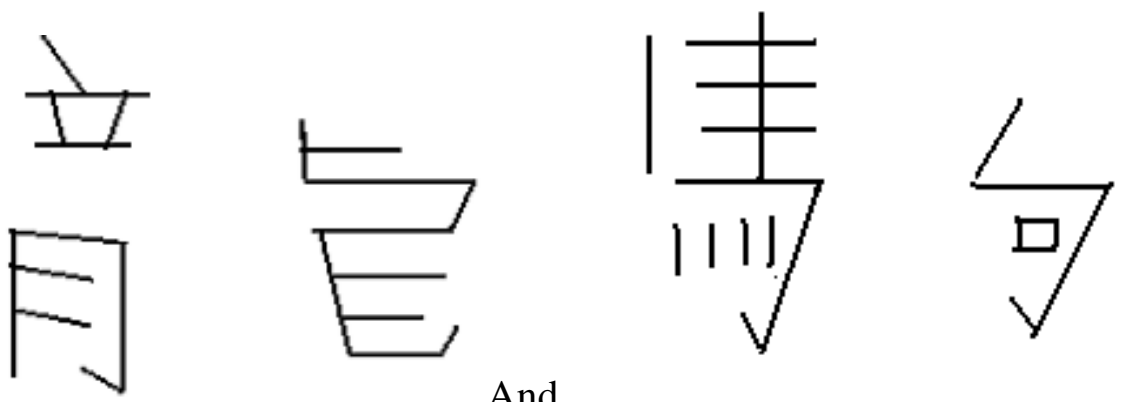

And 
literally stating 'dragonhorse', but which combine to mean figuratively "a horse that is exceedingly swift and beautiful." ${ }^{1}$ Pound, in his translation, has retained the simple suggestiveness of the image emerging from the juxtaposed ideograms.

From this simple example we may observe two of the chief qualities of Chinese imagery: directness and immediacy. These are perhaps the effects Les Imagistes were striving for by emphasizing the unadorned language of common speech and a concentration and concision in expression. These qualities are readily perceived in the imagery and language of Pound's translation 'Exile's Letter'. Note the simplicity but great efficacy, for example, of such metaphors as: 'roads twisted like sheep's guts', 'ripples like dragon-scales, going grass green on the water', 'And the wind lifting the song, and interrupting it,/Tossing it up under the clouds?' This last image is somewhat reminiscent of H.D.'s well-known 'Oread', which was also, incidentally, one of Pound's favorites: ${ }^{2}$

\author{
Whirl up, sea- \\ whirl your pointed pines, \\ splash your great pines \\ on our rocks, \\ hurl your green over us, \\ cover us with your pools of fir.
}

H.D.'s poem serves as an excellent example of Pound's own definition of Imagism, as given in his Literary Essays:

\begin{abstract}
An 'Image' is that which presents an intellectual and emotional complex in an instant of time. I use the term 'complex' rather in the technical sense employed by the newer psychologists ....

It is the presentation of such a 'complex' instantaneously which gives that sense of sudden liberation; that sense of freedom from time limits and space limits; that sense of sudden growth, which we experience in the presence of the greatest works of art (41).
\end{abstract}

\footnotetext{
${ }^{1}$ Here I am indebted to a friend of mine from the Department of Chinese Language and Literature at Erciyes University.

${ }^{2}$ Pound comments, for example, in 'A Retrospect' on 'H.D.'s' [sic] waves like pine tops'.
} 
'Oread' clearly presents a single Image which gains complexity through the merging of generally unassociated, but not wholly dissimilar elements: sea and pine. The brevity of the poem, the intensity of its expression, lacking superfluous connectives, and the subterranean associations of feeling which arise from the merging of sea and pine-all these contribute doubtlessly to that 'sense of freedom from time limits and space limits' which Pound praises. One is led to believe that Pound must have had this poem in mind when he wrote elsewhere that Imagisme is "sculpture or painting . . . forcing itself into words" (Literary Essays 380). Nevertheless, there is an important difference between the imagism of H.D.'s poem and the imagism in the translations of Cathay.

The poetry of Cathay achieves the effect of the unified Image, not so much by the 'playing on' and intensification of one image, as in 'Oread' but by the ideogrammic juxtapositioning of diverse images in such a way that they merge into a unified presentation of the total poem. Unlike the tightly compressed language of 'Oread', the syntax of the Cathay poems is looser and freer, and the imagery, though weaker in intensity, is richer in variety. In this variety, however, lie the beauty and the force of the Cathay poems. Pound's translation of Rihaku's 'Separation on the River Kiang' illustrates well this ideogrammic effectiveness:

Ko-jin goes west from Ko-kaku-ro,

The smoke-flowers are blurred over the river.

His lone sail blots the far sky.

And now I see only the river,

The long Kiang, reaching heaven.

The first line of the poem creates a sense of movement, from east to west, not at all dependent on whether or not the reader understands the references to Ko-jin or Ko-kaku-ro. The following line establishes an image of the time of year, the season of smoke-flowers, of delicate blossoms creating fuzzy forms, clouds, against the background of the river. Perhaps it is spring or early summer. (The Chinese reader would, no doubt, have a decided advantage here.) The third line renders the most striking image of the poem: 'His lone sail blots the far sky'. The reader 
learns at once that Ko-jin is sailing west from Ko-kaku-ro and that he has not yet traveled far, for his sail in the foreground 'blots the far sky'. The masterful juxtaposition of the final image- 'And now I see only the river,/The long Kiang, reaching heaven'.- which avoids the use of artificial transition, indicates that now the traveler has left his companion, the on-looker and poet, far behind. Within the bounds of the natural rhythms of the language of common speech, Pound succeeds in suggesting, rather than presenting fully, an Image of separation and loneliness, which is as visible and profound as the void between the boat's sail in the foreground and the stretch of the river Kiang toward heaven in the distance. Furthermore, this Image - 'an intellectual and emotional complex in an instant of time'-emerges from the careful superposition of image on image.

It is clear from the above poem that the Image, the Ideogram itself, if it is to be effective, depends greatly on the beauty and the force of the image, the ideogrammic component. That Pound was successful in translating the Chinese image is everywhere attested in Cathay. We have already given a few examples from 'Exile's Letter', which is, for the most part, a long narrative poem and not as densely imagistic as many of the other poems in Cathay. Nevertheless, that which ties the poem together is not so much the narrative as the succession of images. Especially poignant is the expression of grief in the lines: 'And if you ask how I regret that parting:/It is like the flowers falling at Spring's end/Confused, whirled in a tangle'. The poet makes no attempt to intellectualize his feelings; that is, he does not step outside them to state them vaguely and inexactly. Rather he shapes feeling into pictures, which may be readily seen and felt.

Sensory perceptions, too, are presented rather than described. In the poem 'Leave-taking near Shoku' the reader is not told that the traveler has ridden high up into the steep mountains of Shoku, but only that 'Clouds grew out of the hill at his horse's bridle'. Or in 'The City of Choan' the poet does not speak directly of the passing of time and mutability of nature, but writes rather that 'the phoenix are at play on their terrace./The phoenix are gone, the river flows on alone'. Note here, as elsewhere, the lack of connectives and superfluous words. In 'The 
River Song' much is compressed into the image: 'Kutsu's prose song/Hangs with the sun and moon'. The image here suggests both the majesty of the song (it soars to the heights of the sun and moon and shares an equal place with them) and its power to illuminate (as in other literatures, the sun and moon are conventional symbols of light in Chinese verse). The intention of light imagery is supported by Robert Payne's translation of the same poem (Yohannan 233): 'The songs of Chu-ping still shine like the sun and moon'. Payne's translation is a statement of the 'shining' of Chu-ping's songs, like the sun and moon, but it lacks the physical dimension, the grandeur, implicit in Pound's image of the 'prose song' hanging above us with the sun and moon. Pound is not merely a translator, but a poet who re-forms his material in the process.

The Imagists concern for concentrated expression and Pound's definition of the Image as 'an intellectual and emotional complex in an instant of time' would lead one to believe, perhaps, that most of the poetry in Cathay would tend toward brevity, as does 'Separation on the River Kiang', for example. Although there are a representative number of short poems in Cathay ${ }^{3}$ - resembling somewhat the Japanese Haiku-the greater number is rather long by comparison. To account for the ability to sustain an Image in a poem of more than a few lines, or even a few stanzas, one must turn again to the effectiveness of ideogrammic juxtaposition. In 'Sennin Poem by Kakuhaku', for example, the long middle stanza presents a series of images that contribute to the overall Image of the 'lone man', playing a stringed instrument, who communicates with the Sennin, spirits of the air:

The red and green kingfishers flash between the orchids and clover,

One bird casts its gleam on another.

Green vines hang through the high forest,

They weave a whole roof to the mountain,

The lone man sits with shut speech,

He purrs and pats the clear strings.

He throws his heart up through the sky,

He bites through the flower pistil

And brings up a fine fountain.

${ }^{3}$ Vide "The Beautiful Toilet," "The Jewel Stairs' Grievance," and Four Poems of Departure. 


\footnotetext{
The red-pine tree god looks at him and wonders.

He rides through the purple smoke to visit the sennin,

He takes "Floating Hill" by the sleeve,

He claps his hand on the back of the great water sennin.

But you, you dam'd crowd of gnats,

Can you even tell the age of a turtle?
}

Here, again, the success of the imagery derives largely from its directness and objectivity. Each line follows the straightforward order of subject, verb, predicate and admits no unnecessary adjectives. To use a Poundian term, this poetry is free of 'slither'.

Also free of slither, yet highly charged emotionally, is perhaps one of the best of the Cathay poems: 'The River-merchant's Wife: A Letter'. This poem illustrates yet another means open to the Imagist to write an extended poem, unlike the usual H.D. single-image poem of several lines, as represented by Pound's own highly acclaimed 'In a Station of the Metro'. In 'The River-merchant's Wife' the poet not only combines discrete images into a larger Image, but also juxtaposes the larger Images, which emerge from various sections of the poem. Thus, ideogramically, Pound describes the maturing, from childhood, of the young wife, along with the ripening of her love for her river-merchant husband. The total Image which finally emerges from the poem-a quiet declaration of the wife's love for her itinerant, distant husband and a deeply moving, almost silent, expression of grief and longing at his absence - is a cumulative experience of all the Images which have gone before. Notice, for example, how the images of childhood and youth in the opening of the poem-'pulling flowers', 'playing horse', 'playing with blue plums' [where 'blue plums' refers to adolescence] - contrast with and therefore intensify the sincere, but simple expression of love in the third stanza: 'I desired my dust to be mingled with yours/Forever and forever and forever'.

Superimposed on this expression of love is the unadorned statement of sadness upon the wife's separation from her husband: 'And you have been gone five months./The monkeys make sorrowful noise overhead'. Even the chatter of monkeys, to her, sounds like a lament. The direct simplicity of this image is reechoed in the delicately passionate final statement of the poem: 
If you are coming down through the narrows of the river Kiang,

Please let me know beforehand,

And I will come out to meet you

As far as Cho-fu-Sa.

Some anthologists err in footnoting the distance to Cho-fu-Sa, believing the reader needs such a crutch. It is sensitively made clear that the River-merchant's wife will go, presumably by foot, as far as she must to meet her husband. This affirmation of her naïve love is given form and definition by the subtle hinting Images that have preceded. Thus, this poem gains an Asian, flower-like beauty, not because of any one line or image, but as a result of melding part into part until the exquisite whole is formed.

Recalling H.D.'s 'Oread', which was quoted earlier, and Pound's definition of the Image as 'an intellectual and emotional complex in an instant of time', it is clear that in Cathay Pound has gone beyond this concept of the Image as a liberating, visual, but instantaneous insight into the poetic experience. Pound demonstrates that the virtues of concision, le mot juste, and crystalline suggestive imagery may be sustained for more than an instant of time. But such suspension of feeling and mood may only be accomplished when one has first learned the secret of a poem like 'Separation on the River Kiang' - an affirmation that 'it is better to present one Image in a lifetime than to produce voluminous works" (Literary Essays 4). Those readers of Pound who focus primarily on The Cantos or 'Mauberley' or 'Propertius'-giving only passing attention to the earlier shorter poems of Personae or his translations of the Anglo-Saxons, the Troubadours, and the Chinese-sadly fail to ground themselves in the first principles of his art. In these earlier works Pound has learned how to amplify Imagistic directness and presentation by enriching the Imagiste approach with the Ideogrammic method, surely a major innovation in twentieth-century poetic art. 


\section{References}

Fenollosa, Ernest. "The Chinese Written Character as a Medium for Poetry" in Prose Keys to Modern Poetry, Karl Shapiro, Ed. New York: Harper and Row 1962.

Pound, Ezra. A Draft of XVI Cantos of Ezra Pound. Paris: 1924-25 (Limited edition).

Pound, Ezra. "A Retrospect" in The Literary Essays of Ezra Pound. New York: New Directions, 1968.

Pound, Ezra The Cantos of Ezra Pound. New York: New Directions, 1963.

Pound, Ezra. "Cathay" in Personae. New York: New Directions, 1957.

Pound, Ezra. "The Chinese Ideogram" in ABC of Reading, New York: New Directions, 1960.

James Scully, Ed. Modern Poetics, New York: McGraw-Hill, 1965.

Thrall, William Flint, Addison Hibbard, and C. Hugh Holman. A Handbook to Literature. New York: Prentice-Hall, 1960.

Yohannan, John D., Ed. A Treasury of Asian Literature. New York: Plume Reissue, 1995. 